komplikasjon til tilstanden. Andre behandlinger som har vært benyttet er korte steroidkurer. Magnesiumsulfat har vært brukt i en del postpartumtilfeller (3).

Pasienten har gitt samtykke til at artikkelen blir publisert.

\section{Mikal Tønsaas \\ mikal@stortorget4.no \\ Legekontoret Stortorget \\ Stortorget 4 \\ 9008 Tromsø}

Stein Harald Johnsen

Nevrologisk avdeling

Marit Seip

Revmatologisk avdeling

Petter Eldevik

Radiologisk avdeling

Universitetssykehuset Nord-Norge
Oppgitte interessekonflikter: Ingen

\section{Litteratur}

1. Moustafa RR, Allen CM, Baron JC. Call-Fleming syndrome associated with subarachnoid haemorrhage: three new cases. J Neurol Neurosurg Psychiatry 2008; 79: 602-5.

2. Call GK, Fleming MC, Sealfon $S$ et al. Reversible cerebral segmental vasoconstriction. Stroke 1988: 19: 1159-70.

3. Moskowitz SI, Calabrese LH, Weil RJ. Benign angiopathy of the central nervous system presenting with intracerebral hemorrhage. Surg Neurol 2007; 67: 522-7

4. Calado S, Viana-Baptista M. Benign cerebral angiopathy; postpartum cerebral angiopathy: characteristics and treatment. Curr Treat Options Cardiovasc Med 2006; 8: 201-12.

5. Dodick DW, Brown RD jr., Britton JW et al. Nonaneurysmal thunderclap headache with diffuse, multifocal, segmental, and reversible vasospasm. Cephalalgia 1999; 19: 118-23.

6. Jackson M, Lennox G, Jaspan T et al. Migraine angiitis precipitated by sex headache and leading to watershed infarction. Cephalalgia 1993; 13 : 427-30.
7. Gautier JC. Segmental cerebral angiopathy of drug addicts. Physiopathological significance. Possible role of spasms. Bull Acad Natl Med 1988; 172: 87-93.

8. Calabrese LH, Dodick DW, Schwedt TJ et al. Reversible cerebral vasoconstriction syndromes. Ann Intern Med 2007; 146: 34-44.

9. Keyrouz S, Dhar R, Axelrod Y. Call-Fleming syndrome and orgasmic cephalgia. Headache 2008; 48: 967-71

10. Arntzen KA, Albretsen C, Bajic R. En eldre kvinne med akutte pareser og synstap. Tidsskr Nor Lege foren 2007; 127: 593-6.

11. Koopman K, Uyttenboogaart M, Luijckx GJ et al. Pitfalls in the diagnosis of reversible cerebral vasoconstriction syndrome and primary angiitis of the central nervous system. Eur J Neurol 2007; 14: $1085-7$.

Manuskriptet ble mottatt 12.5. 2009 og godkjent 2.7. 2009. Medisinsk redaktør Odd Terje Brustugun.

\title{
Kun en skygge av virkeligheten
}

Tønsaas og medarbeidere presenter sykehistorien til en 39 år gammel mann som brått utviklet en intens hodepine. Nevroradiologisk undersøkelse med CT cerebrum viste blod beliggende subaraknoidalt over hjernekonveksitetene. Ved intraarteriell cerebral angiografi fire dager senere fant man intet aneurisme, som primært mistenkt, men betydelige patologiske forandringer med segmentale forsnevringer på alle store hjernearterier. Fire uker senere var pasienten uten hodepine, og ny cerebral angiografi viste komplett normalisering.

Utviklingen innen nevroradiologien har revolusjonert mulighetene for presis diagnostikk og behandling av mange hjernesykdommer. CT- og MR-angiografi har langt på vei erstattet intraarteriell angiografi for diagnostisk bildefremstilling av hjernens arterier. Ikke-invasiv påvisning av arteriell okklusjon ved akutt hjerneinfarkt og aneurisme ved subaraknoidalblødning tar få minutter og gir klinikeren avgjørende informasjon for valg av behandling i akuttfasen. Trass i denne teknologiske suksessen er det viktig å huske at bildedannende metoder kun gir oss «en skygge av virkeligheten» - ikke minst gjelder dette angiografi. Dette er en teknikk som avbilder en kontrastsøyle eller blodstrømmen i et kar, den gir begrenset informasjon om bakenforliggende patofysiologi eller patologisk anatomi. Radiologisk påvist forsnevring på en cerebral arterie kan ha en rekke forklaringer, alt fra reaktiv vasospasme til arteriosklerose, strålingssekvele, infeksjon, karveggsinflammasjon, fibromuskulær dysplasi, neoplasme eller radiologisk artefakt.
Tradisjonelt er et angiografisk funn av utbredte segmentale forsnevringer på en eller flere av hjernens arterier blitt tolket synonymt med cerebral arteritt. Intraarteriell cerebral angiografi er blitt sett på som selve gullstandarden for denne diagnosen. Både primær og sekundær (til ekstrakranial revmatisk sykdom) cerebral arteritt er en ofte progredierende og mulig fatal tilstand som skal behandles med høydosert kortikosteroid og gjerne et cytostatikum (cyklofosfamid). Behandlingen går over måneder til flere år og har en rekke potensielt alvorlige bivirkninger, som osteoporose og diabetes mellitus, og medfører fare for maskering av infeksjon. Dessuten fremmer kortikosteroider arteriosklerose.

Nyere studier sannsynliggjør at cerebral arteritt nok er enda sjeldnere forekommende enn tidligere antatt (1), og at selv gullstandarden intraarteriell cerebral angiografi har for liten sensitivitet og spesifisitet til å stille diagnosen med rimelig grad av presisjon (2). Mange tilfeller av cerebral arteriosklerose og ikke minst av reversibelt cerebral vasokontriksjon-syndrom (3) har vært tolket som cerebral arteritt. Forståelig nok vil en angiografisk normalisering uker til måneder etter oppstart av immunsupprimerende medikasjon lett bli oppfattet som utrykk for positiv behandlingseffekt og gi støtte for videre behandling. Slik angiografisk normalisering kan derimot være helt uavhengig av behandlingen og heller representere reversibelt cerebral vasokonstriksjon-syndrom eller radiologiske artefakter ved primærundersøkelsen. Med tanke på de mange differensial- diagnosene og farene ved tung og langvarig immunsuppressiv behandling bør hjernebiopsi alltid utføres før oppstart av medikamentell behandling, i alle fall på indikasjonen primær cerebral arteritt.

En angiografisk fremstilling av en arterie er kun et øyeblikksbilde. Et minutt, en time eller en uke senere kan arterien ha en helt annen konfigurasjon. Historien om «oppdagelsen» av reversibelt cerebral vasokonstriksjon-syndrom gir oss nok en gang en påminnelse om at «sannheter» $i$ medisinen er ferskvare og at det viktigste for en lege er å se til at den medisinske behandlingen ikke er mer til skade enn til gagn for pasienten.

\section{Christian Lund}

christian.lund@rikshospitalet.no

Nevrologisk avdeling

Oslo universitetssykehus, Rikshospitalet

0027 Oslo

\section{Oppgitte interessekonflikter: Ingen}

\section{Litteratur}

1. Birnbaum J, Hellmann DB. Primary angiitis of the central nervous system. Arch Neurol 2009; 66: $704-9$.

2. Kadkhodayan Y, Alreshaid A, Moran CJ et al. Primary angiitis of the central nervous system at conventional angiography. Radiology 2004; 233: 878-82.

3. Ducros A, Bousser MG. Reversible cerebral vasoconstriction syndrome. Pract Neurol 2009; 9: 256-67.

Manuskriptet ble mottatt 30.9. 2009 og godkjent 15.10. 2009. Medisinsk redaktør Odd Terje Brustugun. 